\title{
Retreating alpine glaciers: increased melt rates due to accumulation of dust (Vadret da Morteratsch, Switzerland)
}

\author{
J. OERLEMANS, R.H. GIESEN, M.R. VAN DEN BROEKE \\ Institute for Marine and Atmospheric Research, Utrecht University, 3508 TA Utrecht, The Netherlands \\ E-mail: j.oerlemans@uu.nl
}

\begin{abstract}
The automatic weather station (AWS) on the snout of the Vadret da Morteratsch, Switzerland, has delivered a unique 12 year meteorological dataset from the ablation zone of a temperate glacier. This dataset can be used to study multi-annual trends in the character of the surface energy budget. Since 2003 there has been a substantial darkening of the glacier tongue due to the accumulation of mineral and biogenic dust. The typical surface albedo in summer has dropped from 0.32 to 0.15 . We have analysed the implications of the lowered albedo for the energy balance and the annual ablation. For the 4 year period 2003-06, the decreased albedo caused an additional removal of about $3.5 \mathrm{~m}$ of ice. Calculations with an energy-balance model show that the same increase in ablation is obtained by keeping the ice albedo fixed to 0.32 and increasing the air temperature by $1.7 \mathrm{~K}$. Our analysis confirms that for retreating glaciers the deposition of dust from exposed side moraines on the glacier surface constitutes an important feedback mechanism. The mineral dust stimulates the growth of algae, lowers the surface albedo, enhances the melt rates, and thereby facilitates the further retreat of the glacier snout.
\end{abstract}

\section{INTRODUCTION}

The retreat of valley glaciers around the world has drawn much attention and is mentioned frequently as a clear and unequivocal sign of global warming. There is no doubt that glaciers react significantly to long-term fluctuations in the temperature of the ambient atmosphere. The reason for this was identified long ago: the ablation rate at a melting glacier surface is sensitive to temperature change (e.g. Angström, 1933; Kuhn, 1989; Ohmura and others, 1992). Higher air temperatures lead to a larger turbulent heat flux to the surface and an increased flux of downwelling longwave radiation from the atmosphere. Because a melting glacier surface cannot raise its temperature, the amount of emitted radiation does not increase and all the surplus energy is used to increase the ablation rate.

The sensitivity of the ablation rate to temperature change can further be enhanced if the albedo is affected. Tongues of retreating glaciers have remarkably low albedos (e.g. Paul and others, 2005, 2007). This is partly due to coverage of the ice by layers of debris (Nakawo and Young, 1982; Mihalcea and others, 2006), and partly because there is a large amount of dust on the ice surface. The dust found on glaciers has a very diverse origin. A significant part consists of humic material, being the residue of bacterial decomposition of organic matter (Takeuchi and others, 2001; Takeuchi, 2002; Fujita, 2007). On many glaciers around the world, there is also an abundance of mineral dust. The deposition of Sahara dust on glaciers in the Alps is a wellknown phenomenon (Sodemann and others, 2006). Figure 1 shows an example of the resurfacing of such a layer in early summer on the Vadret da Morteratsch, Switzerland. Although not very well documented, it is likely that the occasional deposition of mineral dust on glaciers occurs on a regional scale all around the world.

When glaciers have been retreating for some time, exposed side moraines become a large source of mineral dust. The dry and unconsolidated material is easily taken up by wind gusts and deposited tens to hundreds of metres away. This process can be observed on any summer day with fair weather and somewhat windy conditions. The valley of the Vadret da Morteratsch is a clear example, where dust-whirls from the side moraines can be observed frequently. During the past 5 years the lower tongue of the Vadret da Morteratsch has become darker due to the accumulation of dust (Fig. 1). Although the glacier has been retreating for 150 years and high side moraines have long been present, it seems that the warm, dry conditions over the past few years have increased the dust flux from the moraines, and probably also stimulated the growth of snow algae on the glacier surface. At the same time, larger melt rates may have caused an increase in the melt-out of debris contained in the ice.

In the middle of the darkening snout of the Vadret da Morteratsch, an automatic weather station (AWS) was operated by the Institute for Marine and Atmospheric Research, Utrecht University, from October 1995 until May 2007 (on 16 May 2007 the AWS had to be moved a considerable distance up-glacier because the terrain became too irregular and the formation of crevasses threatened the stability of the mast). The AWS has delivered a unique record of the microclimate on a glacier snout. Parts of this record have been analysed with a focus on the surface energy budget (Oerlemans and Knap, 1998; Oerlemans, 2000). The data have also been used extensively to calibrate a mass-balance model for the Vadret da Morteratsch (Klok and Oerlemans, 2002), and to make a comparison with the microclimate of Midtalsbreen, Norway (Giesen and others, 2008).

In this study we take advantage of the long series of measurements provided by the AWS. We investigate the implications of the transition from a relatively clean ice surface to a surface with a high concentration of dust. Since all the components of the surface energy budget can be evaluated, we can draw conclusions about the relative importance of the albedo variations with respect to the interannual differences in ablation. 

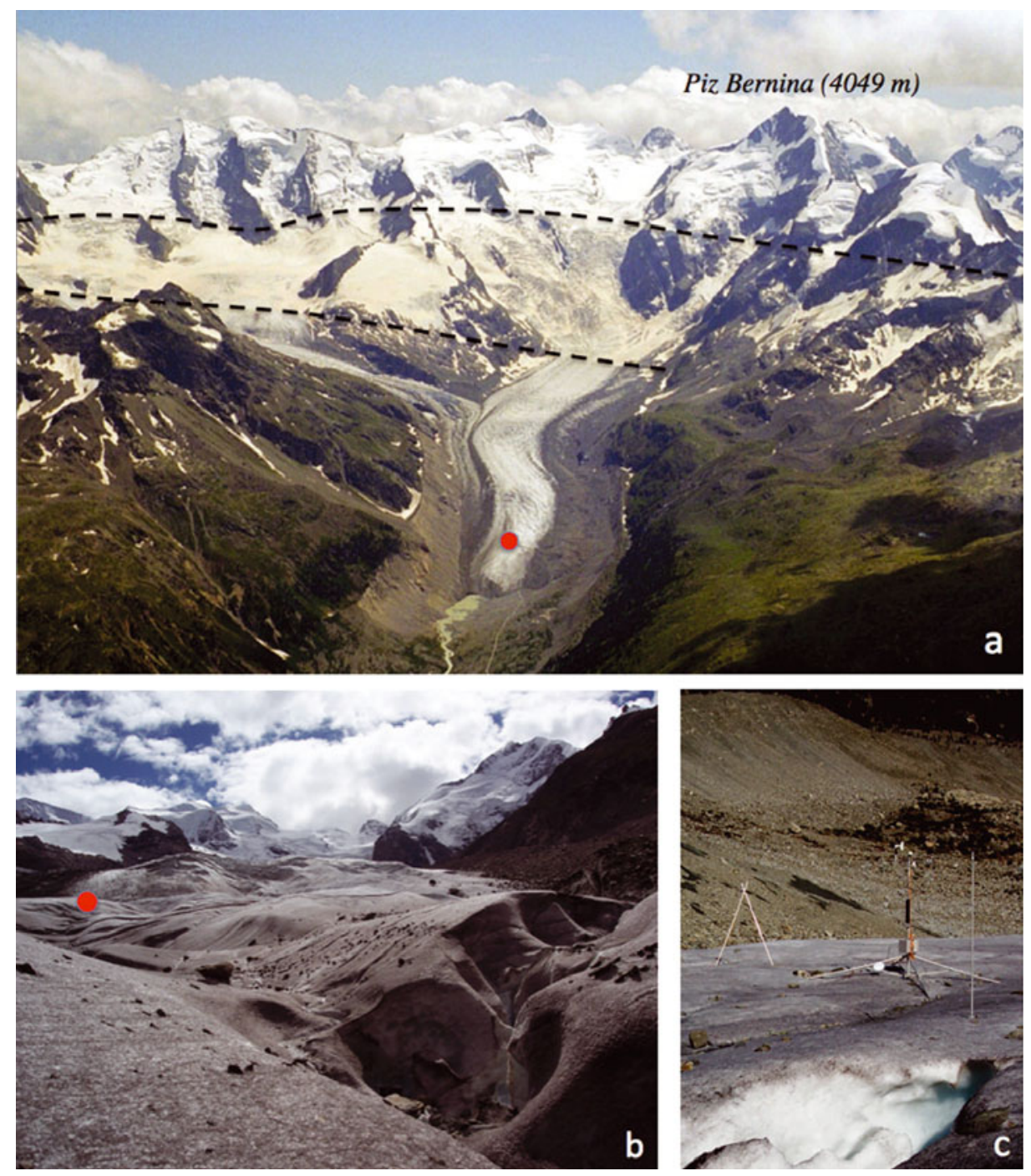

Fig. 1. (a) A southward-looking aerial photograph of the Vadret da Morteratsch (taken by C. Rothenbühler, 26 June 2003). A yellow-coloured Sahara dust band is clearly visible (between the dashed lines). The lower dashed line approximately coincides with the transient snowline. The AWS on the glacier tongue is indicated by the red spot. (b) The lower part of the Vadret da Morteratsch looking south. The meltwater channel in the foreground is about $5 \mathrm{~m}$ deep. (c) Photo of the AWS looking in northwesterly direction, showing the part of the glacier covered by debris as well as one of the side moraines. (Photographs (b) and (c) taken by J. Oerlemans, 13 September 2005.)

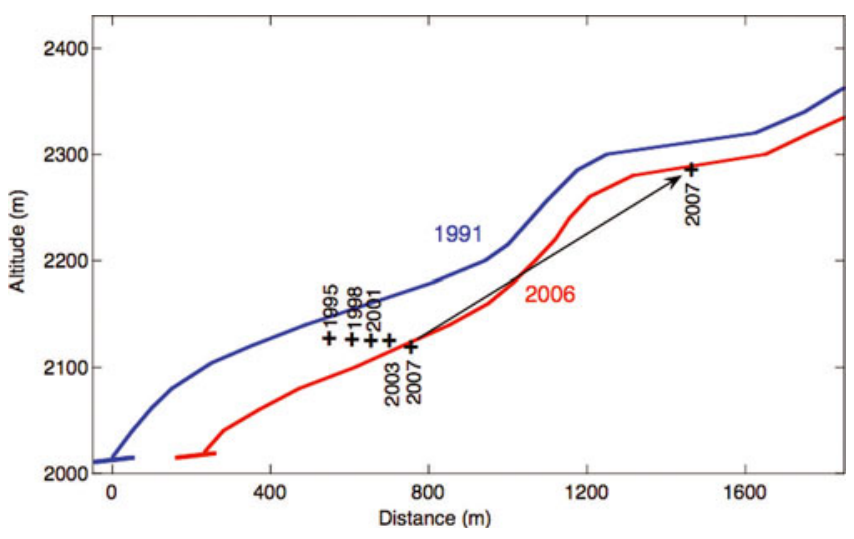

Fig. 2. Location of the AWS in the years that it was put up (1995) or moved to another location $(1998,2001,2003,2007)$. Profiles of the glacier surface were taken from Bundesamt für Landestopographie (1979). The distance is measured from the glacier front position in 1991.

\section{DATA}

The Vadret da Morteratsch is a typical valley glacier, located in the Swiss Alps $\left(46^{\circ} 24^{\prime} \mathrm{N}, 9^{\circ} 56^{\prime} \mathrm{E}\right)$, and flowing in a northerly direction (Fig. 1). It is $7.5 \mathrm{~km}$ long, has an area of about $17 \mathrm{~km}^{2}$ and spans an altitudinal range of over $2000 \mathrm{~m}$. The glacier front is at about $2000 \mathrm{~m}$ a.s.l. The accumulation basin is steep and rugged, whereas the ablation zone has a smaller slope with a few crevassed areas. The equilibrium line is at $\sim 3000 \mathrm{~m}$ a.s.l. The glacier front has retreated over a distance of about $2 \mathrm{~km}$ since the mid-19th century, as witnessed by impressive side moraines.

The AWS was located on the glacier snout (Fig. 1) during the period 1 October 1995 to 15 May 2007, at about $2115 \mathrm{~m}$ a.s.l. It stood on a relatively flat part of the glacier (slope $\sim 5^{\circ}$ ), about $500 \mathrm{~m}$ from the glacier front. The AWS was moved short distances up-glacier on 8 July 1998, 14 July 2001 and 24 September 2003. Care was taken to ensure a very similar surface at the old and new locations. The location of the station is shown in Figure 2. The positions were measured with simple global positioning system (GPS) equipment; it should be noted that the measurements in 
1995 and 1998 were not very accurate $( \pm 25 \mathrm{~m})$ because of horizon obstruction of the surrounding mountains (a small number of satellites were available). Two longitudinal surface profiles passing through the location of the AWS are also shown in Figure 2. It can be seen that between 1991 and 2006 the glacier surface lowered substantially. However, the AWS remained at approximately the same altitude, and the distance between the AWS and the glacier front hardly changed.

On 8 July 1998, the set of sensors on the AWS was replaced and extended. As can be seen in Figure 1c, the AWS consisted of two constructions. The mast carrying the meteorological instruments stood freely on the ice and was sinking with the melting surface. In this way the distance of the instruments to the surface remained approximately constant (nominal value $3.5 \mathrm{~m}$ ) as long as there was no snowpack. The second construction, a tripod, was drilled into the ice. A sonic ranger was mounted on this construction, measuring the distance to the surface. This provided information on ice melt in summer, and on snow accumulation in winter. The set-up was completed by a few aluminum stakes, placed around the station, at which regular readings of snow depth and ice surface were made (typically four times per year).

The meteorological quantities measured were air temperature (usually with forced ventilation), pressure, wind speed and wind direction, incoming and reflected shortwave radiation, incoming and outgoing longwave radiation (since 8 July 1998), and humidity (since 8 July 1998). For an instrument height of $3.5 \mathrm{~m}$ above the surface, the reflected radiation comes from an area with an effective radius of $10 \mathrm{~m}$. The instrument thus 'views' about $300 \mathrm{~m}^{2}$ of the glacier surface. Sampling was done every minute, and $30 \mathrm{~min}$ averages were stored throughout the period. In the record of almost 12 years there are only 20 days of missing data. For more details about the AWS and images of the instruments and the field location, the reader is referred to earlier papers (e.g. Oerlemans, 2000; Oerlemans and Klok, 2002) and to the project website: http//www.phys.uu.nl/ $\sim$ oerlemns/site_Mort/morteratsch.html

\section{SURVEY OF THE DATA}

Figure 3 provides an overview of the weather conditions during the period of observation. All graphs show daily mean values. The daily albedo in Figure $3 c$ is defined as the daily amount of reflected shortwave radiation divided by the daily amount of incoming shortwave radiation (note that this differs from the daily mean albedo). During days with snowfall, the upward-facing radiation sensor is frequently covered by snow, whereas the downward-looking sensor is not. This leads to unrealistically high values of the albedo. For the daily albedo shown in Figure 3c an upper limit has been set to 0.9 .

The 2003 summer is the warmest in the record. In central Europe this summer was exceptional and it has been described and analysed in many papers (e.g. Black and others, 2004; Luterbacher and others, 2004). The largest June-August temperature anomaly was observed in Switzerland (Schär and others, 2004). Here the average summer temperature was $5.1 \mathrm{~K}$ above normal, corresponding to 5.4 times the standard deviation. The record from the Morteratsch AWS is not long enough to make a comparison to these numbers, but judging from Figure 3 a the summer temperature anomaly at the AWS site was smaller, presumably $2-3 \mathrm{~K}$. This is in line with the idea that close to a melting glacier surface, temperature fluctuations are damped.

The daily albedo in summer (Fig. 3c) shows a marked evolution. During the first six summers (1996-2002) a characteristic ice albedo is about 0.3. Occasionally, daily albedo values rise to 0.8 for a few days due to summer snowfalls. A special event occurred on 10-11 July 2000, when an outbreak of polar air brought $0.5 \mathrm{~m}$ of snow at $2500 \mathrm{~m}$ a.s.l. (Oerlemans and Klok, 2004). After the summer of 2001 the ice albedo started to decline steadily, reaching a mean value of 0.14 for the period June-August 2006. This is an extremely low value and we considered whether tilt of the radiation sensor played a role. The tilt was measured manually four times a year, and was invariably $\sim 5^{\circ}$ towards the north, implying that the instrument stayed more-or-less parallel to the glacier surface. In considering potential errors, the ratio of the direct radiation to diffusive radiation, denoted by $\nu$, is a key quantity. Since the AWS site is surrounded by high mountains towards the east, south and west, the solar elevation is always significantly larger than the tilt of the instrument. In fact, the minimum possible solar elevation is $\sim 18^{\circ}$. For the incoming radiation, i.e. the radiation entering the upward-looking sensor, $\nu$ will be larger than for the reflected radiation. This implies that a northward tilt of the sensor will lead to an underestimation of the incoming radiation which is larger than the underestimation of the reflected radiation. Consequently, the northward tilt of the instrument will lead to a value for the albedo that is too large. A systematic calculation of the error is difficult, because this would require the (ever varying) value for $\nu$ to be known. However, a few test calculations show that the error is small $(<5 \%)$. The albedo values shown in Figure 3c can therefore be regarded as realistic.

The longwave balance is shown in Figure $3 \mathrm{~d}$. The outgoing longwave flux at the surface cannot exceed the flux for a melting surface, which is about $315 \mathrm{~W} \mathrm{~m}^{-2}$. However, since the sensor is mounted at a height of about $3.5 \mathrm{~m}$, there can be a contribution from the air between the surface and the sensor. The measured flux can therefore be slightly larger than $315 \mathrm{~W} \mathrm{~m}^{-2}$. The pattern in the longwave fluxes is fairly regular. Notable are the rather large values of the incoming longwave radiation in the winter of 2006/07, which are due to the relatively high air temperatures. Daily averages of the net longwave flux are rarely positive. Only on warm and not too dry summer days do slightly positive values occur.

The net radiation is shown in Figure 3e. The steady increase through the years due to the decrease of the albedo is clearly seen. The asymmetry around mid-summer is noteworthy. The increase in net radiation is very steep in late spring/early summer due to the transition from a snowcovered to a bare ice surface. The transition from bare ice to snow cover in late fall/early winter has a more limited effect because then the incoming shortwave radiation flux is small.

More detail about the varying albedo is shown in Figure 4. Daily albedos for every year for the period 1 May-31 October are plotted together to bring out the interannual differences more clearly. Even during summer a large variability is apparent. Several processes may cause shortterm albedo variations (Adhikary and others, 2000; Brock and others, 2000; Klok and others, 2003; Brock, 2004). Summer snowfall events have the most pronounced effect. The case of 10 July 2000 was studied in detail by Oerlemans 

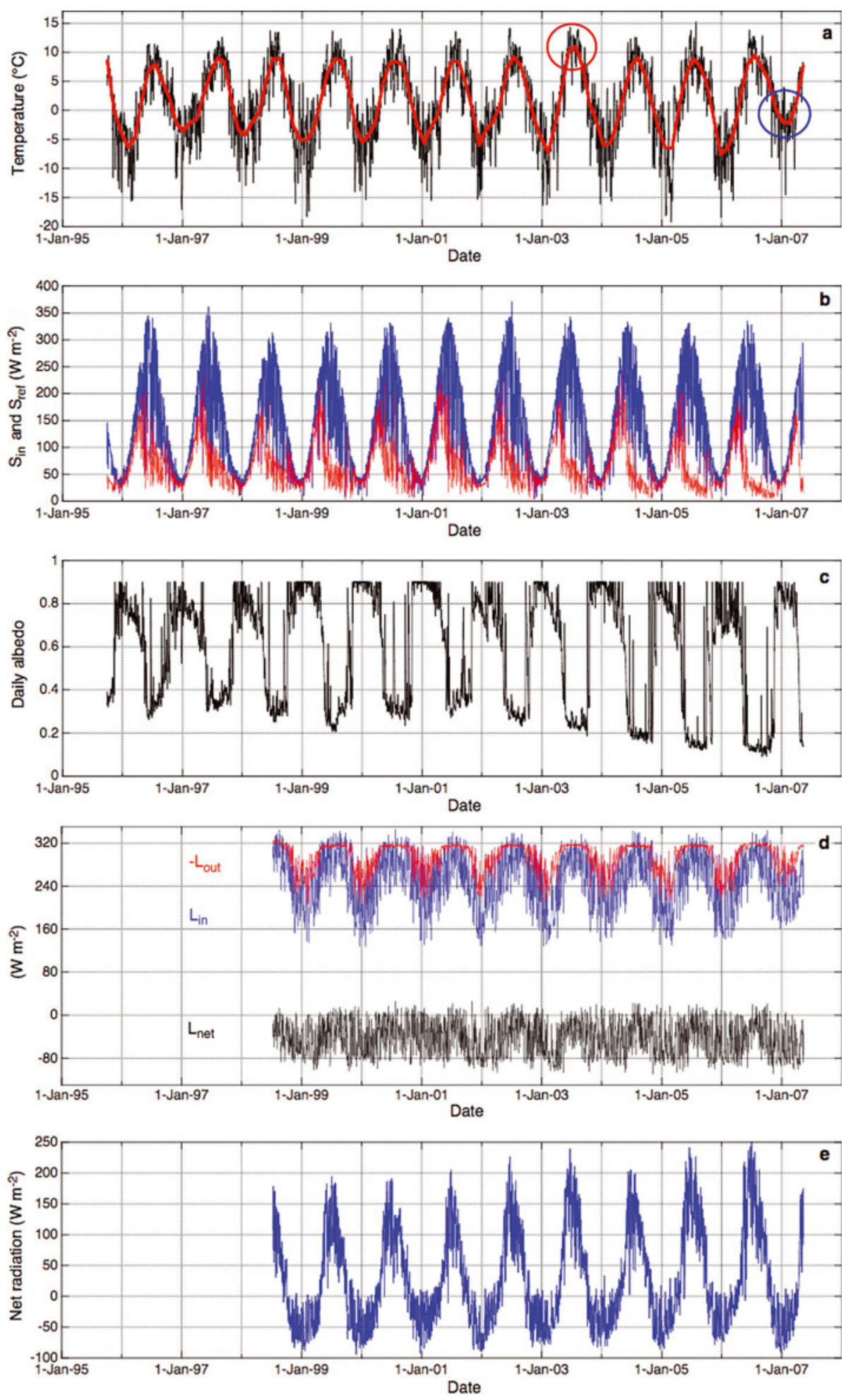

Fig. 3. A survey of basic data for the entire record (daily mean values). (a) Air temperature (low-pass filtered in red); (b) incoming shortwave radiation $\left(S_{\text {in, }}\right.$, blue) and reflected shortwave radiation $\left(S_{\text {ref, }}\right.$ red); (c) daily albedo; (d) components of the longwave radiation flux; and (e) net radiation. In (a), the very warm summer of 2003 is indicated by a red circle, the very mild winter of 2006/07 by a blue circle.

and Klok (2004). Other processes, like rainfall events, meltout of dust layers, and variations in cloud cover, all play a significant role. The ratio of subsurface melt (related to shortwave radiation) to surface melt (related to longwave radiation and turbulent heat flux) is another important factor. In considering albedo variations in the course of a summer, it should also be noted that the radiation instrument is not level and that the tilt may change by a few degrees in the course of the summer. A detailed analysis of short-term albedo variations (e.g. Brock, 2004) would be seriously hampered by the fact that the data are from an AWS, and that manual observations on meteorological conditions are not available. We therefore think it is not meaningful to speculate about the causes of albedo variations within a summer, and we focus on the long-term trend.

Figure 5 shows the surface height as measured by the sonic ranger. For every year the height is set to zero on 1 October. Note that the surface height is not an absolute 


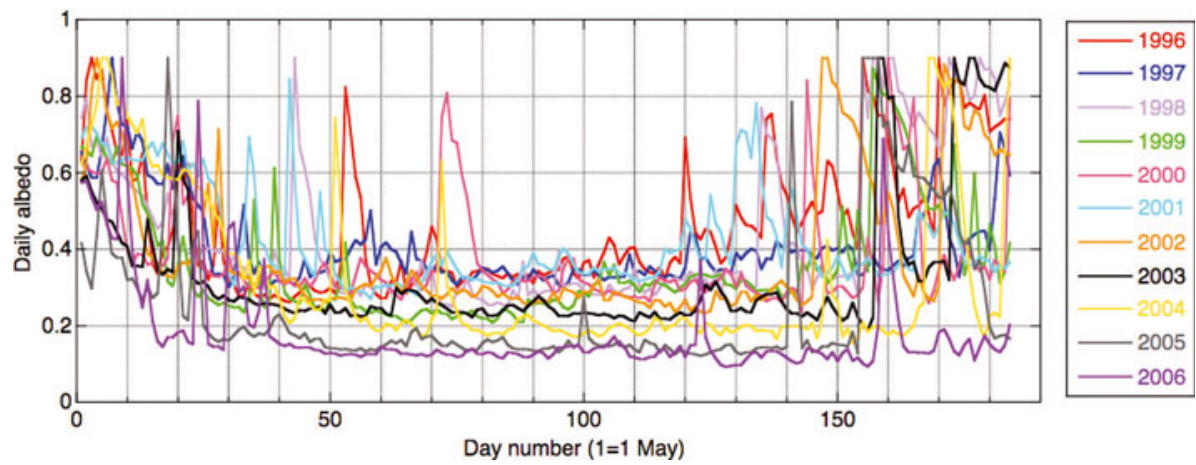

Fig. 4. Daily albedos for the period 1 May-31 October. Data are the same as in Figure 3c, but plotted as a function of day number.

height, but refers to a material surface inside the glacier. This material surface is defined by the lower ends of the stakes that form the tripod on which the sonic ranger is mounted (Fig. 1c). In most years, there is still some surface lowering in October, and significant snowfalls normally do not occur before November. A typical maximum snow depth on the glacier snout is $\sim 1 \mathrm{~m}$, showing that the Vadret da Morteratsch is located in a dry region. The maximum snow depth occurred in the winter of 2000/01, whereas in the winter of 2004/05 there was hardly any snow. The typical mean balance rate $\bar{b}$ over the years studied is about $-6.3 \mathrm{mice}^{-1}$. Three years have distinctly lower values: 2002/03, 2004/05 and 2005/06. The low value for the 2002/ 03 balance year is first of all due to the high summer temperatures referred to above. For the balance year 2004/ 05 the ice melt in October as well as the small amount of winter snow played an important role. As shown in the next

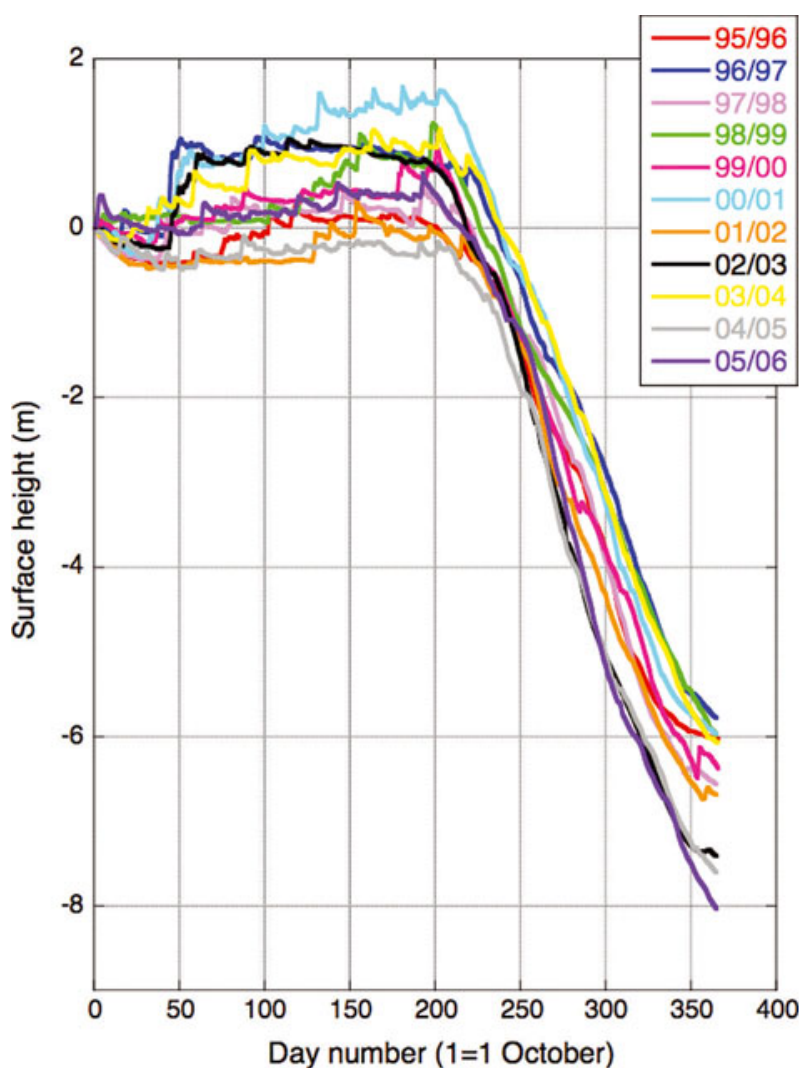

Fig. 5. Surface height as measured by the sonic ranger for 11 balance years. On 1 October the height is set to zero. section, the low surface albedo was the primary cause for the low balance rate in 2005/06.

\section{ANALYSIS OF THE SURFACE ENERGY BUDGET}

To bring out the effect of a changing ice albedo, we analyse the surface energy budget with a surface energy balance model (Van den Broeke and others, 2005). The energy balance at the glacier surface can be written as

$$
Q=S_{\text {in }}+S_{\text {ref }}+L_{\text {in }}+L_{\text {out }}+H_{\text {sen }}+H_{\text {lat }}+G,
$$

where $Q$ is the melt energy $(Q=0$ if the surface temperature is below the melting point), $S_{\text {in }}$ and $S_{\text {ref }}$ are incoming and reflected solar radiation, $L_{\text {in }}$ and $L_{\text {out }}$ are incoming and outgoing longwave radiation, $H_{\text {sen }}$ and $H_{\text {lat }}$ are the turbulent sensible and latent heat fluxes and $G$ is the subsurface heat flux. All fluxes are defined positive when directed towards the surface. Heat supplied by rain is neglected, which is justified on glaciers with a considerable mass turnover (Oerlemans, 2001). Penetration of shortwave radiation is not included either. Although the amount of shortwave radiation entering the upper ice layers can be considerable, it merely implies that part of the melting occurs in the subsurface ice instead of at the surface. This does not significantly affect total melt.

The model determines the surface energy balance in Equation (1) for a skin layer without heat capacity. $S_{\text {in, }} S_{\text {ref }}$ and $L_{\text {in }}$ are taken from the measurements, and the other fluxes are formulated as functions of the surface temperature $T_{\mathrm{s}}$. The model time-step is $10 \mathrm{~min}$ to keep changes in $T_{\mathrm{s}}$ between time-steps small and to determine accurately when the surface is melting. To obtain model input for every timestep, the AWS data are linearly interpolated between halfhourly values. Using an iterative procedure, the surface energy balance is solved for $T_{\mathrm{s}}$. If $T_{\mathrm{s}}$ found by the model is higher than the temperature of the melting point, $T_{\mathrm{s}}$ is set back to $0^{\circ} \mathrm{C}$ and the excess energy is used for melting. The amount of melt $M$ (in mw.e.) is calculated by dividing $Q$ by the latent heat of fusion $\left(3.34 \times 10^{5} \mathrm{~J} \mathrm{~kg}^{-1}\right)$ and the density of water $\left(1000 \mathrm{~kg} \mathrm{~m}^{-3}\right)$. The turbulent fluxes are calculated with the bulk method, based on differences in wind speed, potential temperature and specific humidity between a measurement level and the surface (for a detailed description, see Van den Broeke and others, 2005). On glaciers, katabatic winds often have a wind-speed maximum within the first metres above the surface. Assumptions made in Monin-Obukhov similarity theory, on which the bulk method is based, are not valid in the presence of a windspeed maximum. Still, the bulk method has been found to 


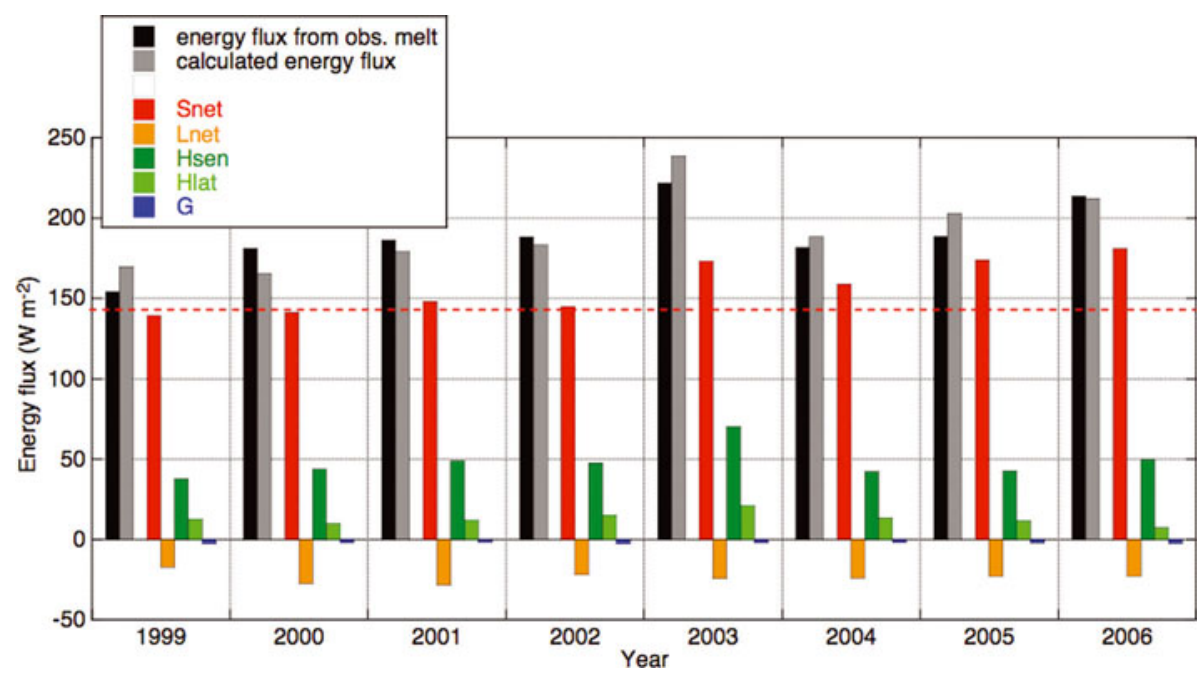

Fig. 6. Mean surface energy fluxes for the summers of individual years (JJA). The dashed red line refers to the mean 1999-2002 value of the net shortwave flux.

give good results when the measurement level is below the wind-speed maximum (Denby and Greuell, 2000). For the surface roughness length for momentum we use a value of $0.13 \mathrm{~mm}$ when the surface is covered by snow, and a value of $0.75 \mathrm{~mm}$ when the surface consists of ice. The scalar roughness lengths for heat and moisture are calculated following the method of Andreas (1987).

The subsurface heat conduction is computed from the one-dimensional heat-transfer equation for $0.04 \mathrm{~m}$ thick layers down to $20 \mathrm{~m}$ depth. The temperature at the lowest level is assumed to remain constant. The initial temperature profile is generated by running the model in a continuous loop over the measurement period until the $20 \mathrm{~m}$ temperature becomes stationary within $0.01 \mathrm{~K}$. The number of snow layers in the model is determined by dividing the observed snow depth by the model layer thickness. Meltwater is routed vertically through the snowpack and refreezes where snow temperatures are below the melting point. Snow density is kept constant at $300 \mathrm{~kg} \mathrm{~m}^{-3}$, based on measurements in snow pits around the AWS. Hence, refreezing only affects the temperatures in the snowpack, not the density. When the snowpack is saturated with meltwater, the remaining meltwater is assumed to run off. The model does

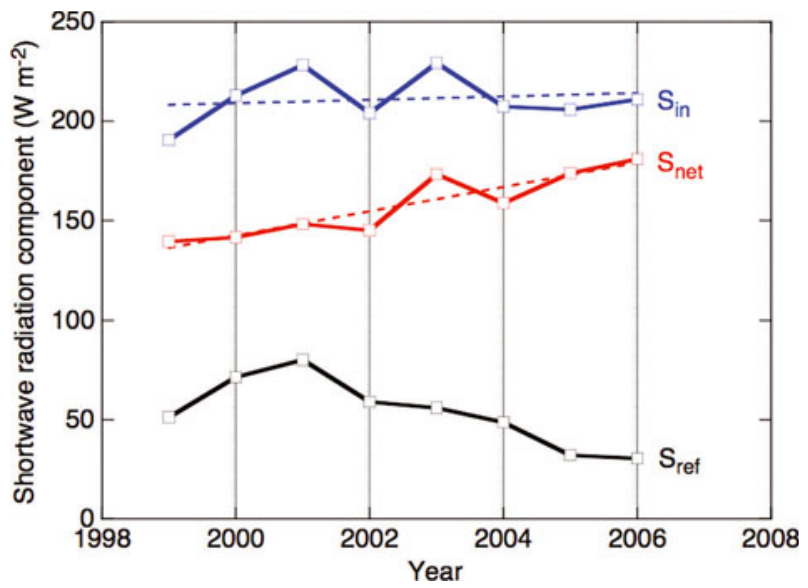

Fig. 7. Components of the shortwave radiation budget in summer for individual years (JJA). The effect of the decreasing albedo on the net shortwave radiation is evident. not keep track of the changing depth of the snowpack; the record from the sonic ranger is used instead. When the snow has disappeared, input from the height sensor is not needed anymore and model and measurements are independent. For this snow-free period, the melt, $M$, computed by the model can be compared with the surface lowering registered by the sonic ranger and the ablation stakes by dividing $M$ by 0.9 , the ratio of the ice and water densities used here.

We now consider the results from the energy-balance calculation and focus on the summer period (June-August; abbreviated as JJA). During this period the surface is almost continuously melting. We refer to the ablation in this period as the summer ablation. In Figure 6 the mean melt energy and the components of the surface energy budget are shown for the years 1999-2006. In general, there is good agreement between the energy flux calculated directly from the measured ablation and the energy flux obtained from the model with the meteorological data as input. The rootmean-square difference is $11.7 \mathrm{~W} \mathrm{~m}^{-2}$, which is about $6 \%$ of the mean flux of melt energy. The largest ablation occurs in the warm summer of 2003, and is due to a large turbulent heat flux as well as a large net shortwave flux. The subsurface energy flux is negligibly small in all years, which is to be expected during melting conditions on the lower tongue of a temperate glacier.

A remarkable feature is the much larger net shortwave flux for the last 4 years (2003-06) as compared to the first 4 years (1999-2002). To elucidate this further, the components of the shortwave radiation budget are shown in Figure 7. Obviously there is no trend in the incoming radiation, whereas the reflected radiation balance decreases substantially. We carried out a simple $t$ test to estimate the statistical significance of the trend in the JJA mean shortwave radiation. The significance appears to be just at the $5 \%$ level.

To compare interannual changes in the net shortwave radiation with changes in the other components of the surface energy budget, we calculated the standard deviation $(\sigma)$ from the eight annual (JJA) data points. The values are listed in Table 1 . The reflected shortwave radiation has the largest value of $\sigma$, followed by the turbulent flux (defined here as the sum of the sensible heat flux and the latent heat flux). The incoming longwave radiation shows a remarkably small variation. Altogether we may conclude that changes in 
Table 1. Statistics of the components of the surface energy balance during summer (JJA). The reflected shortwave radiation shows the largest variation within the 8 year sample (bold)

\begin{tabular}{lrr}
\hline & Mean & Std dev. \\
& $\mathrm{W} \mathrm{m}^{-2}$ & $\mathrm{~W} \mathrm{~m}^{-2}$ \\
\hline Total melt energy JJA & 189.5 & 20.8 \\
Shortwave in & 211.2 & 12.8 \\
Shortwave reflected & -53.4 & $\mathbf{1 7 . 3}$ \\
Longwave in & 290.3 & 3.5 \\
Longwave out & -316.0 & 0.8 \\
Turbulent flux & 60.8 & 13.1 \\
Subsurface heat flux & -2.2 & 0.3 \\
& & \\
\hline
\end{tabular}

albedo related to the dust load on the glacier surface have dominated the variation in the surface energy balance.

Another method to investigate the importance of the decreasing ice albedo is to rerun the energy-balance model with a fixed ice albedo (denoted by $\alpha_{\mathrm{fix}}$ ), and compare the result with the standard calculation discussed above. There are different possibilities to define $\alpha_{\text {fix }}$. We have chosen to use a value that gives a perfect match between the observed and calculated cumulative balance on 1 January 2003. In this way we have found $\alpha_{\text {fix }}=0.32$.

Figure 8 shows how the cumulative balance differs between the fixed ice albedo run and the run with observed albedo from 1 January 2003. At the end of the melt season in 2006, the difference in ice melt between the standard run (curve a in Fig. 8) and the fixed albedo run (curve b in Fig. 8) is $3.32 \mathrm{~m}$ w.e. This demonstrates that the lowering of the surface albedo has considerable influence on the annual ablation.

To add a further perspective to this result, we repeated the energy-balance calculation with an increased air temperature and a constant ice albedo of 0.32. The temperature was simply increased by an amount $\Delta T$ from 1 January 2003. An increasing air temperature affects the turbulent fluxes as well as the downwelling longwave radiation $\left(L_{\text {in }}\right)$. The turbulent fluxes are implicitly adjusted in the model, but this does not apply to $L_{\text {in }}$. Measured values of $L_{\text {in }}$ were increased by $4.2 \mathrm{~W} \mathrm{~m}^{-2} \mathrm{~K}^{-1}$, corresponding to an effective atmospheric emissivity of 0.8 (this value is based on an analysis of the AWS data). Furthermore, the relative humidity was kept constant (i.e. equal to the measured value), implying that the specific humidity increases with temperature. The value of $\Delta T$ was varied to find out what temperature increase would have the same effect as the decreased albedo. As illustrated by curve c in Figure 8 , with $\Delta T=1.7 \mathrm{~K}$ the amount of ice melt at the end of the period is virtually identical to the original calculation with the measured ice albedo.

\section{CONCLUSION AND DISCUSSION}

The long series of meteorological measurements on the snout of the Vadret da Morteratsch makes it possible to study trends in the energy and mass budget of a glacier surface on multiannual timescales. Here we have analysed the effect of accumulation of dust on the melt process. Lowering of the albedo by dust turns out to be a very effective process to enhance the summer melt rate. The equivalent temperature rise of $1.7 \mathrm{~K}$ needed to generate the same increase in melt rate demonstrates the significance of the accumulation of dust.

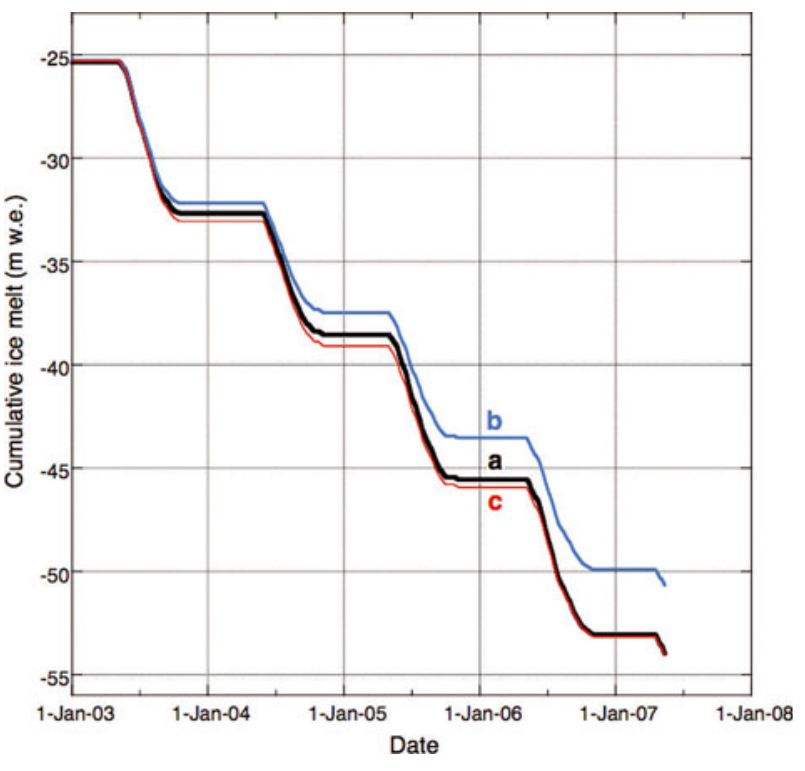

Fig. 8. Calculated ice melt for (a) the standard input data, (b) a run with constant ice albedo and (c) a run with constant ice albedo and a $1.7 \mathrm{~K}$ temperature increase since 2003.

Although the dataset we used is comprehensive, a few questions remain that cannot be answered with the available data. First, it is not clear why the accumulation of dust has increased so much since 2003. We do not believe that it is a source effect: the high side moraines have already been exposed for many decades. It could be, however, that dry conditions have facilitated the transport of dust from the moraines to the glacier surface. Although precipitation measurements from the Morteratsch valley are not available, data from weather stations in the region show that the period 2005-07 was dry. The maximum snow depth measured at the AWS site on the glacier tongue was exceptionally small: about $30 \mathrm{~cm}$ in winter 2004/05, $60 \mathrm{~cm}$ in winter 2005/06, and $35 \mathrm{~cm}$ in winter 2006/07. For the period 1995-2003, the average maximum snow depth was about $1 \mathrm{~m}$. We have no direct observations of the duration of the snow cover on the moraines. Nevertheless, it is likely that during years with a shallow maximum snowpack the total flux of mineral dust into the air is larger.

We have demonstrated that the accumulation of dust on the snout of the Vadret da Morteratsch affects the local balance rate significantly. However, it is difficult to extrapolate this result to the entire glacier and give a value for the mean balance rate. The deposition of dust and growth of algae will decrease up-glacier, and the albedo effect will fade out in the highest part of the glacier. Perhaps it is possible to investigate this by a careful evaluation of satellite albedos (Klok and Oerlemans, 2003), although retrieving accurate maps of albedo from satellite images in alpine terrain remains challenging.

\section{REFERENCES}

Adhikary, S., M. Nakawo, K. Seko and B. Shakya. 2000. Dust influence on the melting process of glacier ice: experimental results from Lirung Glacier, Nepal Himalayas. IAHS Publ. 264 (Symposium at Seattle 2000 - Debris-Covered Glaciers), 43-52.

Andreas, E.L. 1987. A theory for the scalar roughness and the scalar transfer coefficients over snow and sea ice. Bound.-Layer Meteorol., 38(1-2), 159-184. 
Ångström, A. 1933. On the dependence of ablation on air temperature, radiation and wind. Geogr. Ann., 15(4), 264-271.

Black, E., M. Blackburn, G. Harrison, B. Hoskins and J. Methven. 2004. Factors contributing to the summer 2003 European heatwave. Weather, 59(8), 217-223.

Brock, B.W. 2004. An analysis of short-term albedo variations at Haut Glacier d'Arolla, Switzerland. Geogr. Ann., Ser. A, 86A(1), 53-65.

Brock, B.W., I.C. Willis and M.J. Sharp. 2000. Measurement and parameterization of albedo variations at Haut Glacier d'Arolla, Switzerland. J. Glaciol., 46(155), 675-688.

Bundesamt für Landestopographie. 1979. Landeskarte der Schweiz, Blatt 1277, Piz Bernina. 1:25.000. Wabern, Bundesamt für Landestopographie.

Denby, B. and W. Greuell. 2000. The use of bulk and profile methods for determining surface heat fluxes in the presence of glacier winds. J. Glaciol., 46(154), 445-452.

Fujita, K. 2007. Effect of dust event timing on glacier runoff: sensitivity analysis for a Tibetan glacier. Hydrol. Process., 21(21), 2892-2896.

Giesen, R.H., M.R. van den Broeke, J. Oerlemans and L.M. Andreassen. 2008. Surface energy balance in the ablation zone of Midtdalsbreen, a glacier in southern Norway: interannual variability and the effect of clouds. J. Geophys. Res., 113(D21), D21111. (10.1029/2008JD010390.)

Klok, E.J. and J. Oerlemans. 2002. Model study of the spatial distribution of the energy and mass balance of Morteratschgletscher, Switzerland. J. Glaciol., 48(163), 505-518.

Klok, E.J., W. Greuell and J. Oerlemans. 2003. Temporal and spatial variation of the surface albedo of Morteratschgletscher, Switzerland, as derived from 12 Landsat images. J. Glaciol., 49(167), 491-502.

Kuhn, M. 1989. The response of the equilibrium line altitude to climatic fluctuations: theory and observations. In Oerlemans, J., ed. Glacier fluctuations and climatic change. Dordrecht, etc., Kluwer Academic Publishers, 407-417.

Luterbacher, J., D. Dietrich, E. Xoplaki, M. Grosjean and H. Wanner. 2004. European seasonal and annual temperature variability, trends, and extremes since 1500. Science, 303(5663), 1499-1503.

Mihalcea, C., C. Mayer, G. Diolaiuti, A. Lambrecht, C. Smiraglia and G. Tartari. 2006. Ice ablation and meteorological conditions on the debris-covered area of Baltoro glacier, Karakoram, Pakistan. Ann. Glaciol., 43, 292-300.
Nakawo, M. and G.J. Young. 1982. Estimate of glacier ablation under a debris layer from surface temperature and meteorological variables. J. Glaciol., 28(98), 29-34.

Oerlemans, J. 2000. Analysis of a 3 year meteorological record from the ablation zone of Morteratschgletscher, Switzerland: energy and mass balance. J. Glaciol., 46(155), 571-579.

Oerlemans, J. 2001. Glaciers and climate change. Lisse, etc., A.A. Balkema.

Oerlemans, J. and E.J. Klok. 2002. Energy balance of a glacier surface: analysis of automatic weather station data from the Morteratschgletscher, Switzerland. Arct. Antarct. Alp. Res., 34(4), 477-485.

Oerlemans, J. and E.J. Klok. 2004. Effect of summer snowfall on glacier mass balance. Ann. Glaciol., 38, 97-100.

Oerlemans, J. and W.H. Knap. 1998. A 1 year record of global radiation and albedo in the ablation zone of Morteratschgletscher, Switzerland. J. Glaciol., 44(147), 231-238.

Ohmura, A., P. Kasser and M. Funk. 1992. Climate at the equilibrium line of glaciers. J. Glaciol., 38(130), 397-411.

Paul, F., H. Machguth and A. Kääb. 2005. On the impact of glacier albedo under conditions of extreme glacier melt: the summer of 2003 in the Alps. EARSeL eProc., 4(2), 139-149.

Paul, F., A. Kääb and W. Haeberli. 2007. Recent glacier changes in the Alps observed from satellite: consequences for future monitoring strategies. Global Planet. Change, 56(1-2), 111-122.

Schär, C. and 6 others. 2004. The role of increasing temperature variability in European summer heatwaves. Nature, 6972(427), 332-336.

Sodemann, H., A.S. Palmer, C. Schwierz, M. Schwikowski and H. Wernli. 2006. The transport history of two Saharan dust events archived in an Alpine ice core. Atmos. Chem. Phys., 6(3), 667-688.

Takeuchi, N. 2002. Optical characteristics of cryoconite (surface dust) on glaciers: the relationship between light absorbency and the property of organic matter contained in the cryoconite. Ann. Glaciol., 34, 409-414.

Takeuchi, N., S. Kohshima, T. Shiraiwa and K. Kubota. 2001. Characteristics of cryoconite (surface dust on glaciers) and surface albedo of a Patagonian glacier, Tyndall Glacier, Southern Patagonia Icefield. Bull. Glaciol. Res. 18, 65-69.

Van den Broeke, M.R., C.H. Reijmer, D. van As, R.S.W. van de Wal and J. Oerlemans. 2005. Seasonal cycles of Antarctic surface energy balance from automatic weather stations. Ann. Glaciol., 41, 131-139. 